\title{
Use of Pollen from a Somatic Hybrid between Citrus and Poncirus in the Production of Triploids
}

\author{
Iwao Oiyama, Shozo Kobayashi, and Katsuichi Yoshinaga \\ Akitsu Branch, Fruit Tree Research Station, Akitsu, Hiroshima 729-24, \\ Japan
}

\section{Toshifumi Ohgawara and Shigetaka Ishii \\ Research and Development Division, Kikkoman Corporation, Noda City, Ciba 279, Japan}

Additional index words. citrus breeding, embryo culture, polyploidy

Triploid citrus scion cultivars have been generated from diploid $\times$ tetraploid crosses (Soost and Cameron, 1980, 1985). Although tetraploids are not themselves commercially useful, they are important as parents for breeding triploids. It may be possible to produce triploids from wider crosses, using tetraploid somatic hybrids as parents. Our study was undertaken to produce triploids from a diploid $\mathrm{x}$ tetraploid cross by using an intergeneric somatic hybrid of Citrus and Poncirus as the pollen parent.

The monoembryonic diploid cultivar Clementine mandarin (Citrus chementina Hort. ex Tanaka) was used as the female parent. The pollen parent was a clone (CP-1) of tetraploid somatic hybrids produced between diploid 'Trovita' sweet orange [ $C$. sinensis (L.) Osbeck] and diploid trifoliate orange [ Poncirus trifoliata (L.) Raf.] (Ohgawara et al., 1985). Hand pollination was carried out immediately following emasculation of the flowers. The seeds were taken from each fruit 7 months after pollination. Among a total of 286 seeds from 15 fruit, three were well developed and the rest were underdeveloped (Fig. 1A). Of the underdeveloped seeds, 78\% were monoembryonic and had small globular embryos lacking cotyledons at the micropylar region (Fig. 1B); the rest were polyembryonic.

Triploid hybrids from diploid $\mathrm{x}$ tetraploid

Received for publication 4 Sept. 1990. Contribution no. E-134 of the Fruit Tree Research Station. The cost of publishing this paper was defrayed in part by the payment of page charges. Under-postal regulations, this paper therefore must be hereby marked advertisement solely to indicate this fact. crosses have been obtained by culturing immature embryos of underdeveloped seeds (Starrantino and Recupero, 1981). In the present study, the embryos excised from underdeveloped, monoembryonic seeds at maturity were cultured on a Murashige and Tucker (1969) medium supplemented with 1 $\mathrm{mg}$ gibberellic acid $\left(\mathrm{GA}_{3}\right)$ /liter (Kochba et al., 1974) and held at 25C with a 16-h photoperiod $\left(25 \mu \mathrm{mol} \cdot \mathrm{m}^{-2} \cdot \mathrm{s}^{-1}\right)$. By this method, embryos began to germinate within 3 to 5 days following the initiation of culture, and seedlings were obtained from $95.5 \%$ of the culture embryos. All seedlings were determined to be triploid $(2 n=27)$ by chromosome counts made on root-tip cells according to the method of Oiyama (1981) and all had trifoliate leaves, The seedlings obtained from fully developed seeds were tetraploid ( $2 n=$ 36) and also had trifoliate leaves, as determined by germinating the embryos on moistened filter paper in a petri dish. Tetraploidy in diploid $\times$ tetraploid crosses of Citrus resulted from the union of unreduced female gametes and reduced male gametes (Esen and Soost, 1972); this may also explain the origin of our tetraploid seedlings. Tetraploid somatic hybrids, with good pollen fertility, may be useful as pollen parents in producing triploid hybrids from crosses with diploids.

\section{Literature Cited}

Esen, A. and R.K. Soost. 1972. Tetraploid progenies from $2 \times \times 4 \times$ crosses of Citrus and their origin. J. Amer. Soc. Hort. Sci. 97:410-414.

Kochba, J., J. Button, P. Spiegel-Roy, C.H. Bormann, and M. Kochba. 1974. Stimulation of rooting of Citrus embryoids by gibberellic acid and adenine sulphate. Ann. Bot. 38:794-802. Murashige, T. and D.P.H. Tucker. 1969. Growth

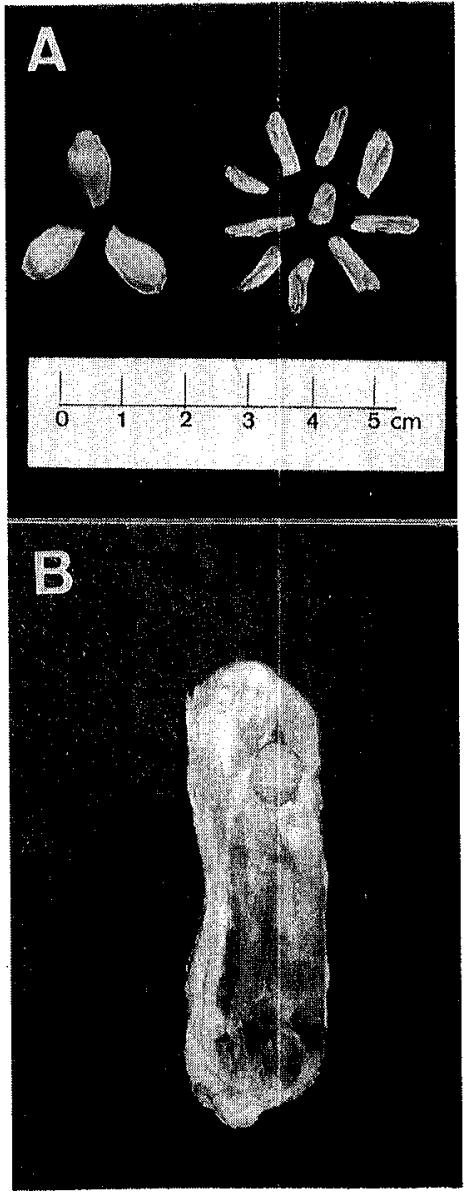

Fig. 1. (A) Normal (left) and underdeveloped (right) seeds and (B) embryo in underdeveloped seed at maturity from diploid 'Clementine' mandarin crossed with tetraploid somatic hybrid.

factor requirements of citrus tissue culture. Proc. First Intl. Citrus Symp. 3:1151-1161.

Ohgawara, T., S. Kobayashi, K. Ohgawara, H. Uchimiya, and S. Ishii. 1985. Somatic hybrid plants obtained by protoplast fusion between Citrus sinensis and Poncirus trifoliata. Theor. Appl. Genet. 71:1-4

Oiyama, I. 1981. A technique for chromosome observation in root tip cells of citrus. Bul. Fruit Tree Res. Sta. D (Kuchinotsu) 3:1-7.

Soost, R.K. and J.W. Cameron. 1980. 'Oroblanco', A triploid pummelo-grapefruit hybrid. HortScience 15:667-669.

Soost, R.K. and J.W. Cameron. 1985. 'Melogold', A triploid pummelo-grapefruit hybrid. HortScience 20:1134-1135.

Starrantino, A. and G.R. Recupero. 1981. Citrus hybrids obtained from $2 \times$ female $\times 4 \times$ males Proc. Intl. Soc. Citricult. 1:31-32. 